\title{
Serum Total Protein Measurement
}

National Cancer Institute

\section{Source}

National Cancer Institute. Serum Total Protein Measurement. NCI Thesaurus. Code C61033.

A quantitative measurement of the total amount of protein present in a sample of serum. 